\title{
Research Article \\ Piezoelectric Configuration for Generating Electricity Using Waves Power
}

\author{
A. Arbie (D, Z. A. Hasan, and A. W. Nuayi \\ Physics Department, Faculty of Mathematics and Natural Sciences, Gorontalo State University, Bone Bolango, Gorontalo, Indonesia \\ 96119 \\ Correspondence should be addressed to A. W. Nuayi; wahidin.awn2023@ung.ac.id
}

Received 17 June 2021; Revised 25 November 2021; Accepted 8 December 2021; Published 27 December 2021

Academic Editor: Mohammad Khan

Copyright (C) 2021 A. Arbie et al. This is an open access article distributed under the Creative Commons Attribution License, which permits unrestricted use, distribution, and reproduction in any medium, provided the original work is properly cited.

\begin{abstract}
This study is aimed at determining the piezoelectric configuration for generating electricity from wave power through the design of a prototype model named Cov-TOTal. The study was carried out in Tomini Bay, Lopo Village, Batudaa Pantai District, Gorontalo Regency, located at approximately \pm 50 meters from the shoreline, while the piezoelectric construction was arranged in parallel with varying numbers of 28,70 , and 90 pieces. The result showed that the amount of piezoelectric configuration affects the value of the voltage and electric current generated by the Cov-TOTal model. Furthermore, the average electric voltage values were $17.58,20.76$, and 29.85 volts, while the average current was $1.16,1.73$, and $2.01 \mathrm{~mA}$ for each piezoelectric amount. Therefore, the largest values of power and electrical energy for each piezoelectric are $16.65 \mathrm{~mW}$ and 0.56 joules, $31.82 \mathrm{~mW}$ and 1.20 joules, and $44.59 \mathrm{~mW}$ and 1.77 joules, respectively. This study concluded that the amount of piezoelectric configuration has a significant effect on the voltage, current, power, and electrical energy produced.
\end{abstract}

\section{Introduction}

Piezoelectricity is the accumulation of electric charge in certain solid materials such as ceramics, bone, and crystals. This phenomenon was discovered by the Curie brothers in 1880, by observing the semiconductor crystals that generated electricity due to the presence of external mechanical stress. The linear electromagnetic interaction of mechanical and electrical parts in the piezoelectric crystal material forms the positive and negative parts of the electrodes, which causes an accumulation of electric charges [1]. Furthermore, the deflection (direct piezoelectric) and the vibrations were produced by the electricity which comes from the pressure, pull, or vibration applied to the piezoelectric material [2].

The deflection process in this piezoelectric material arises from the pressure applied directly or vibrated through an intermediary, such as a cantilever [3]. In consequence, if the applied pressure is large, the electrical voltage which will be generated by this piezoelectric material is going to be even greater which tends to be damaged without direct pressure being applied [4].
Generally, artificial piezoelectric materials include $\mathrm{BaTiO}_{3}$ (barium titanate), PZT (lead zirconium titanate), $\mathrm{PbTiO}_{3}$ (lead titanate), PVDF (polyvinylidene difluoride), $\mathrm{GaPO}_{4}$ (gallium orthophosphate), and $\mathrm{La}_{3} \mathrm{Ga}_{5} \mathrm{SiO}_{14}$ (langasite) [2]. These materials are elastic and flexible; therefore, the ceramic crystals have a sufficiently low dielectric [5].

For practical purposes, piezoelectric crystals on the market can be found in various forms, such as in the shape of a circular chip, which is generally used as a component of a microphone or loudspeaker [6]. Furthermore, due to their ability to convert kinetic, pressure, or vibration energy into electrical energy $[7,8]$, ceramics and piezoelectric crystals can be used as harvesting energy systems [9].

Several studies have found that piezoelectric chips arranged in parallel produce an output voltage of $0.702 \mathrm{~V}$ and an electric current of $50 \mathrm{~A}$ [10]. Meanwhile, those arranged in series produce $10.366 \mathrm{~V}$ [11], $14.2 \mathrm{~V}$ [6], and $80 \mathrm{~V}$ with an electric current of $938 \mathrm{~A}$ [12]. The electric power generated from piezoelectric is $2.166 \times 10^{-6} \mathrm{kWh}$ [3], $3.476 \times 10^{-10} \mathrm{~kW}$ [13], and $4.92 \times 10^{-9} \mathrm{~kW}$ [14]. The 
ratio between the output power of a piezoelectric sensor arranged in parallel $\left(61.50 \times 10^{-9} \mathrm{~kW}\right)$ and series $\left(19.49 \times 10^{-9} \mathrm{~kW}\right)$ is $3: 1$ [15].

The use of sea waves to generate electric power has been widely carried out, including through a generator model based on gravity and water mass [16], turbine blade design [17], and oscillating water column (OWC) [18-20]. Furthermore, Nuh and Hendrowati [13] and Murray and Rastegar [21] researched the use of piezoelectric as a power station using ocean waves. However, the difference with this study lies in the design of the prototype model which is used to take advantage of the motion of the up and down waves as a mechanical stressor to the piezoelectric circuit. The following difference lies in the amount of piezo and the type of piezoelectric used in the configuration.

Therefore, based on the potential of piezoelectric materials as a power station, and the abundant availability of sea waves in Indonesia, this study is aimed at providing information on the effect of the piezoelectric configuration placed on the prototype model, to generate electricity.

\section{Methodology}

2.1. Location and Time of Research. The study was carried out in the waters of Tomini Bay, in Lopo Village, Batudaa Pantai Subdistrict, Gorontalo Regency, with data collected at $0^{\circ} 29^{\prime} 40.5^{\prime \prime} \mathrm{N}$ and $123^{\circ} 01^{\prime} 21.7^{\prime \prime} \mathrm{E}$ and a distance of \pm 50 meters, from the shoreline.

\subsection{Research Procedure}

2.2.1. Model Design Construction. The conversion model of wave power to electric power using a piezoelectric (CovTOTal) was developed and designed in the form of a miniprototype. This was carried out to ensure the available materials such as boards and pipes that function as beaters, buoys, piezoelectric stands, and chips are circular with a diameter of $35 \mathrm{~mm}$. The prototype of the CovTOTal model developed is shown in Figure 1, while the size of the components used in the modeling process is shown in Table 1.

The piezoelectric configuration used in the COv-TOTaL model is arranged in parallel, with the connection between each piezoelectric to the rectifier, which is a circuit used to change alternating current (AC) to direct current (DC) (as shown in Figure 2).

To stay afloat, the diameter of the pipe utilized in the buoy section was made larger than the diameter on the support for the piezoelectric circuit and therefore the pole that connects the swing and batting board. The diameters of the pipe used in the buoy section and other parts are $5.08 \mathrm{~cm}$ and $1.2 \mathrm{~cm}$.

To keep the piezoelectric circuit dry, the height of the piezoelectric stand holder pipe is set as high as $37 \mathrm{~cm}$ from the float pipe, and the piezoelectric circuit is placed on the holder of the circuit wrapped within the plastic. This circuit is deliberately protected by a series holder due to the nature of the piezoelectric material which suffers damage when direct pressure is applied [4].

2.2.2. Testing of Piezoelectric Models and Circuits. Sea waves are used to determine whether the stability, balance, and functions of all the components are following the expected results of the designed Cov-TOTaL model.

The piezoelectric circuit testing is performed in the laboratory by determining the presence of an electric current and voltage on the multimeter when the piezoelectric pressure is applied. The pressure is applied by pressing each arranged piezoelectric model arranged in series. After testing the Cov-TOTal model and the piezoelectric circuit, the design is replicated with circuits comprising of 28,70 , and 90 pieces.

2.2.3. Data Collection. The required data is collected by taking into account the determining parameters, such as wind and wave speed during the measurement process. Furthermore, the physical parameters measured directly in the data collection process are voltage and electric current when the piezoelectric is pressurized through a beater that moves up and down due to waves and the voltage that is successfully stored in the rechargeable battery after 5 minutes. This measurement process is carried out for approximately 25 minutes. The reason for choosing the material in this study is when compared with supercapacitors, the value of battery energy density remains better in comparison to supercapacitors. So far, the value of energy density ranges from 0.1 to $100 \mathrm{Wh} \mathrm{kg}^{-1}$ below the battery whose value ranges from 8 to $300 \mathrm{Wh} \mathrm{kg}^{-1}$ [22].

The electric current and voltage generated by the piezoelectric, as well as those stored in the battery, are measured for each circuit by determining the effect of the piezoelectric keeping arrangement density placed on the prototype.

The density of the piezoelectric circuit is obtained by comparing the area of the piezoelectric circuit board on the prototype model with those in parallel using

$$
\delta_{P z}=\frac{A_{P z} x N_{P z}}{A_{P d}} \times 100 \%,
$$

where:

$\delta_{P z}:$ piezoelectric array density

$A_{P z}$ :piezoelectric area $\left(\mathrm{m}^{2}\right)$

$N_{P z}$ :the number of piezoelectric pieces in each circuit

$A_{P d}$ :piezoelectric circuit board area $\left(\mathrm{m}^{2}\right)$.

The process of measuring the current and voltage generated by each piezoelectric circuit is carried out 50 times, and the average is taken. This is aimed at determining the level of accuracy and reliability of the data obtained.

2.3. Data Analysis. The electric current and voltage generated by the pressure of the batting board that moves up and down due to waves are used to determine the power and electrical energy generated by the piezoelectric. 


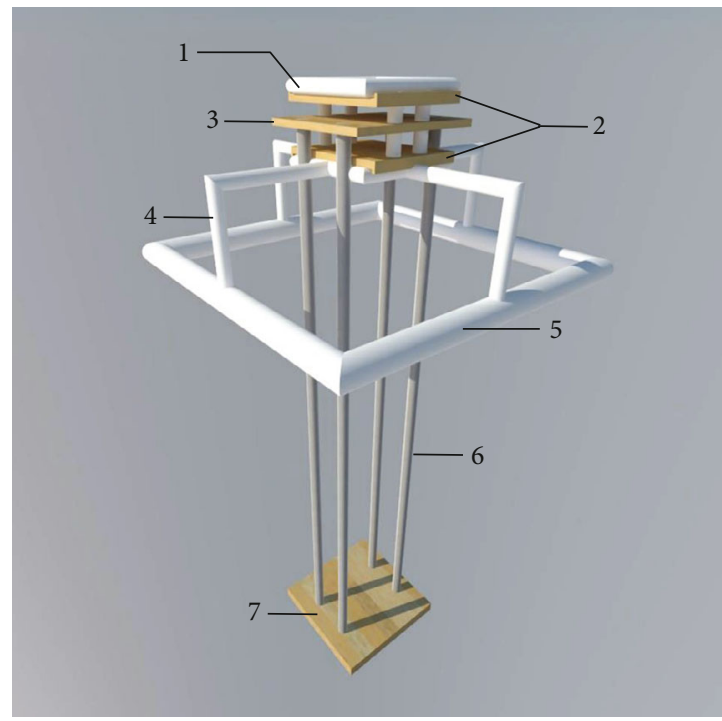

1. Piezoelectric protector

2. Piezoelectric circuit

holder

3. Piezoelectric batting

board

4. Piezoelectric holder

support pipe

5. Float pipe

6. Pole

7. Swing board

(a)

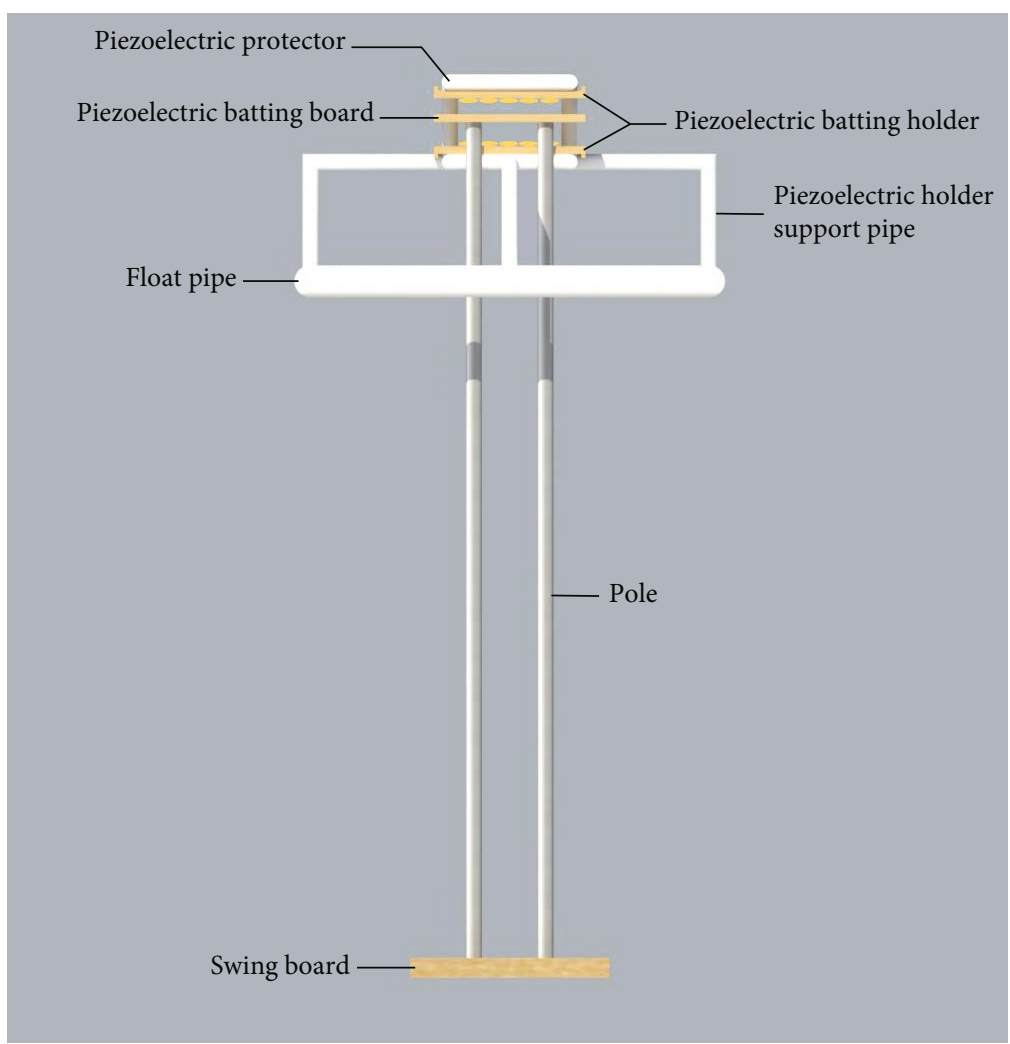

(b)

Figure 1: Cov-TOTal model: (a) side view; (b) front view.

The electric power generated is calculated using

$$
P=V \times I,
$$

where:

$P$ :power (watt)

$V$ :voltage (volts)

I:electric current (ampere).
Equation (2) is used to calculate the energy generated by the piezoelectric and the voltage data stored in the capacitor used with a capacitance value of $2200 \mu \mathrm{F}$.

$$
E=\frac{1}{2} C V^{2}
$$

where:

E:energy (joule) 
TABle 1: Cov-TOTAL model component size.

\begin{tabular}{lr}
\hline Component & Size \\
\hline Piezoelectric protector & $37 \times 37 \mathrm{~cm}$ \\
Piezoelectric circuit holder & $37 \times 37 \mathrm{~cm}$ \\
Piezoelectric batting board & $39 \times 39 \mathrm{~cm}$ \\
Piezoelectric holder support pipe & $37 \mathrm{~cm}$ \\
Float pipe & $110 \times 110 \mathrm{~cm}$ \\
Pole & $200 \mathrm{~cm}$ \\
Swing board & $80 \times 80 \mathrm{~cm}$ \\
The distance between the two piezoelectric circuit holders & $10 \mathrm{~cm}$ \\
Piezoelectric & $3.5 \mathrm{~cm}$ \\
Rectifier & RB208 \\
Capacitor & $1.5 \mathrm{~A}$ \\
\hline
\end{tabular}

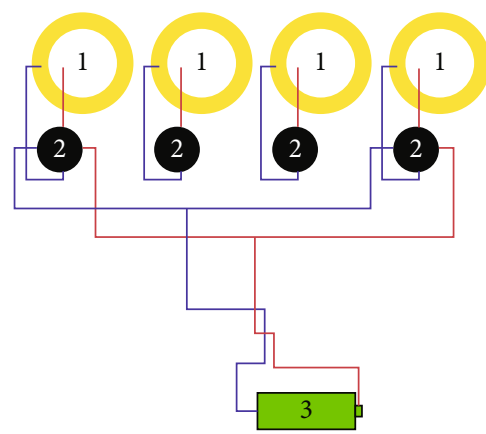

1. Piezoelectric

2. Rectifier

3. Battery

FIgURe 2: Piezoelectric circuit diagram.

C:capacitance (farad)

$V$ :voltage (volt).

\section{Results and Discussion}

3.1. Cov-TOTal Model Prototype. The Cov-TOTaL model converts wave power into electricity through the up and down movement of the swinging plate and the bat board moved by the waves, thereby exerting pressure on the piezoelectric circuit placed on the seat. The batting board is flanked by two piezoelectric stands arranged at a distance of $10 \mathrm{~cm}$, which moves freely in an upward and downward direction hitting the piezoelectric holder at the top and bottom. Therefore, this research determines the stability testing of the prototype model, including the swinging board and paddle to move vertically up and down, stay afloat, and generate electricity when placed on the prototype model building.

Figure 3 shows that the tested prototype form of the Cov-TOTal model has an overall length and width of $1.10 \mathrm{~m}$ with a height of $2.65 \mathrm{~m}$ (including the length of the pole connecting the swing board and the piezoelectric beater). Besides, the area of the swing board, batting board,

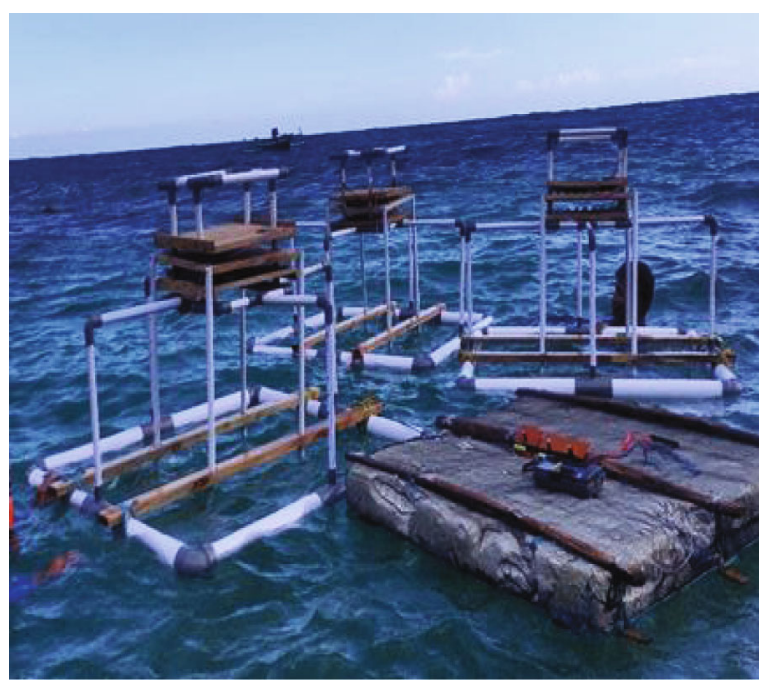

FIgure 3: Testing the Cov-TOTal prototype model.

and holder of the piezoelectric circuit are $0.64,0.15$, and $0.14 \mathrm{~m}^{2}$, respectively.

Piezoelectrics are assembled in parallel by dividing equally the top and bottom parts of the prototype model as shown in Figure 1. When the total number of piezoelectrics used is 98 pieces, therefore, as many as 49 piezoelectrics are assembled and equally placed on the top and bottom parts of the holder (as shown in Figure 4).

The placement of the piezoelectric circuit on the rectangular piezoelectric board with a total area of $0.14 \mathrm{~m}^{2}$ is not entirely occupied by the circle with a diameter of $3.5 \mathrm{~cm}$. Therefore, the area on the board occupied by the circuit or the density that occupies the mounting board of the circuit is required. This is to determine whether the density arranged in parallel on the seat of the circuit also affects the measurement results of the voltage and electric current produced.

Based on Equation (1), each configuration of the number of piezoelectrics arranged in parallel of 28,70 , and 98 pieces has a density of $9.83,24.59$, and $33.72 \%$, respectively. 


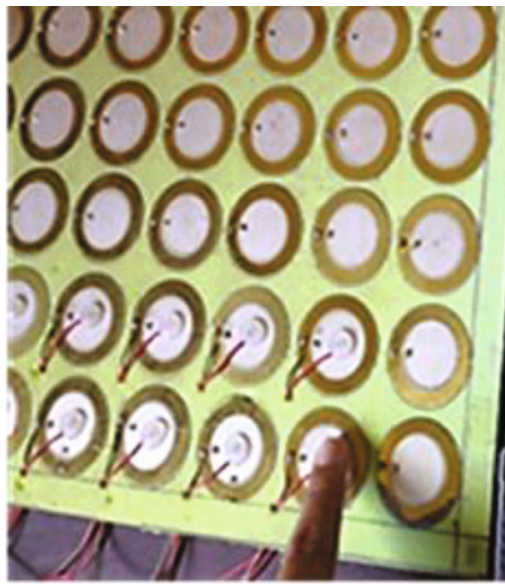

(a)

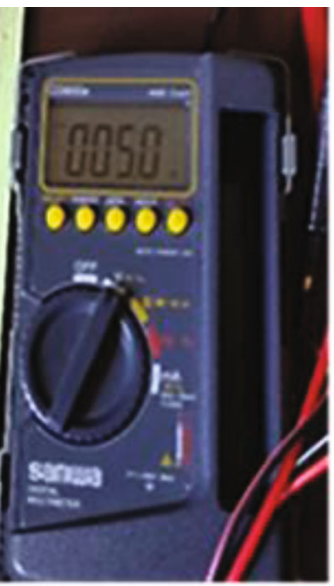

Figure 4: (a) Piezoelectric circuit testing; (b) placement of the circuit.

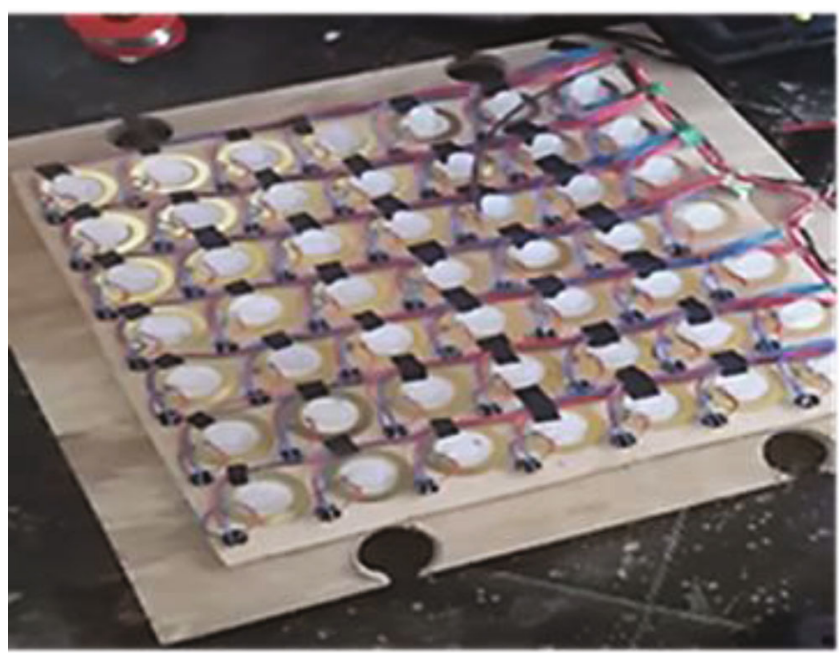

(b)
3.2. Voltage and Electric Current. The periodic up and down movement of the batting board due to the waves on the prototype Cov-TOTaL model provides continuous pressure on the piezoelectric circuit, which is converted into electricity and stored in a capacitor/storage battery. Furthermore, the measurement of the amount of voltage and electric current generated by the piezoelectric shown in Figure 5 indicates that the variation in the configuration of the piezoelectric number affects the measured voltage and electric current.

Figure 5 shows that the addition of the piezoelectric number in the prototype model leads to an increase in the measured voltage and electric current by 2.5 times. Therefore, the initial amount improves in the average voltage and electric current of 18.12 and $49.17 \%$, from $17.58 \mathrm{~V}$ and $1.16 \mathrm{~mA}$ to $20.76 \mathrm{~V}$ and $1.73 \mathrm{~mA}$, respectively. Furthermore, when the piezoelectric count was made 3.5 times, the average voltage and electric current increased by 69.85 and $73.03 \%$ to $29.85 \mathrm{~V}$ and $2.01 \mathrm{~mA}$.

Although the increase in the magnitude of the generated voltage and electric current due to the piezoelectric number configuration was not significant, Figure 4 shows that the measured minimum voltages are $13.10,13.60$, and $22.80 \mathrm{~V}$, with maximum values of $35.80,36.50$, and $51.00 \mathrm{~V}$. The same condition is also shown in the measurement results of the piezoelectric generation electric current for each configuration of the piezoelectric amount. The minimum measured electric currents were $0.89,1.25$, and $1.49 \mathrm{~mA}$, and the maximum electric currents were 2.27, 2.88, and $3.82 \mathrm{~mA}$, respectively.

The configuration of the piezoelectric amount influences the value of the generated voltage and electric current. According to Abrol and Deepak [23], the value of the voltage generated by a double piezoelectric circuit in parallel is greater than using a piezoelectric.

The increase in the trendline graph of the comparison of voltage and electric current with the piezoelectric amount shown in Figure 5 is following the existing theory. This increase is because the piezoelectric acts as a load or resistance that is flowed by an electric current in parallel; therefore, the voltage value increases with a rise in the number of piezoelectric pieces [13].

Furthermore, the conversion of pressure exerted by the waves on the batting board into electricity by piezoelectrics is because it is made of semiconductor crystals of silicon and germanium [2]. This characteristic enables the piezoelectric to convert the kinetic energy produced by waves into electrical energy [7].

The pressure exerted on the model causes a deflection, which leads to a linear electromagnetic interaction of the mechanical and electrical parts. Therefore, some parts of the material become positively charged, while others consist of negative electrodes, which cause the accumulation of an electric charge on the piezoelectric section [1]. Therefore, the greater the pressure applied, the greater the voltage and electric current generated by this piezoelectric material [3, 7].

The values of voltage and electric current obtained in this study are similar to several studies on the use of piezoelectric to produce energy. In this study, the average measured voltage and current values were $17.58-29.85 \mathrm{~V}$, and the average measured electric current was $1.16-2.01 \mathrm{~mA}$, while several studies showed that the voltage and electric current generated by the piezoelectric were $5.08 \mathrm{~V}$ and $10.2 \mathrm{~mA}$ [24], $3.5 \mathrm{~V}$ and $100 \mathrm{~mA}$ [25], $4 \mathrm{~V}$ and $0.015 \mathrm{~A}$ [26], $2.3 \mathrm{mV}$ [27], and $0.9 \mathrm{~V}$ [28].

Figure 6 shows a varying value of voltage and electric current during the measurement process for each configuration of the piezoelectric number due to wind. The value of the minimum voltage and electric current for each configuration of the piezoelectric quantity is measured at the minimum speed. Furthermore, the maximum voltage and electric current values are also measured when the wind is at maximum speed. This is because, at a low-speed level, the wind causes a small wave height and vice versa [18]. Wind speed 


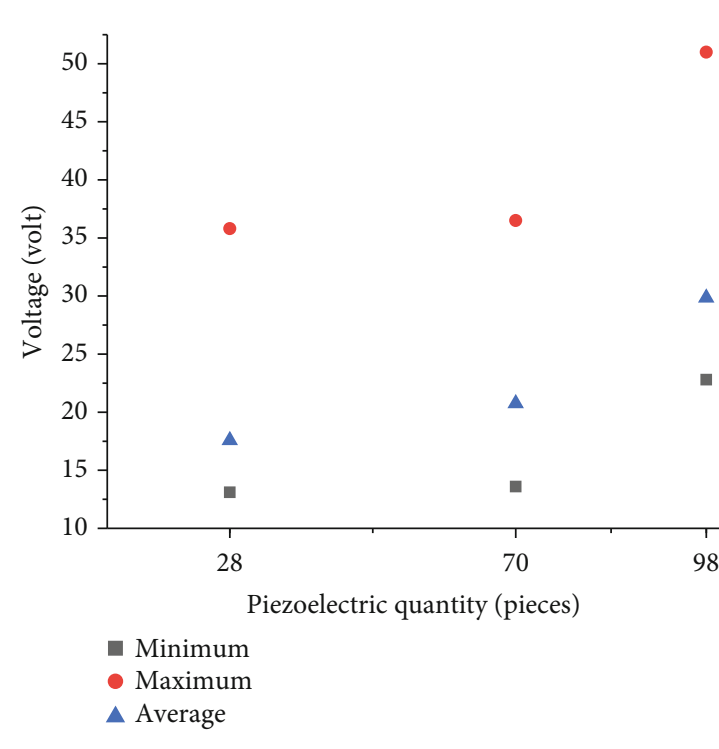

(a)

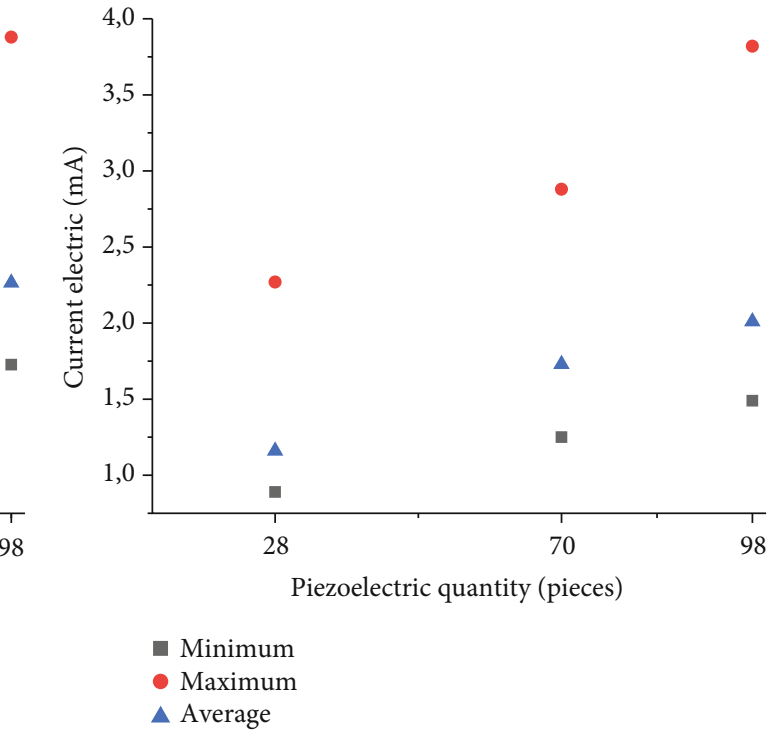

(b)

Figure 5: Piezoelectric (a) voltage; (b) electric current.

measurements at the time of data collection varied with a minimum, maximum, and average speed of $2.3 \mathrm{~m} / \mathrm{s}, 4.5 \mathrm{~m} /$ $\mathrm{s}$, and $3.59 \mathrm{~m} / \mathrm{s}$, respectively.

The variation in wave amplitude caused by varying wind speed to the piezoelectric generated shows that an increase in wave amplitude leads to a rise in voltage and electric current generated. Ocean wave force is the input for the prototype mechanism of this Cov-TOTaL model, with a rise in wave force leading to an increase in the force exerted by the piezoelectric bat. The wave force is directly proportional to the strike exerted by the batting board on the piezoelectric. Therefore, the greater the deflection in the piezoelectric, the higher the voltage and the electric current it generates.

3.3. Power and Electrical Energy. The amount of power and electrical energy generated by the piezoelectric is calculated using Equations (2) and (3). Table 2 shows that the value of the electric power generated through the Cov-TOTaL model is influenced by the measured voltage and current which shows in Figure 6. Therefore, based on the data shown in Table 2, it can be seen that the generated power due to the voltage and electric current generated by the piezoelectric for each configuration varies. The average electric power values for the piezoelectric totals 28,70 , and 98 are 20.39, 35.92, and $59.92 \mathrm{~mW}$, respectively. Meanwhile, the average electrical energy produced is $0.3398,0.4741$, and $0.9803 \mathrm{~J}$.

Table 2, therefore, concluded that the rise in the number of piezoelectrics used leads to an increase in the average power generated. This is based on the nature of the piezoelectric which when given pressure or vibration will produce an electric voltage. The compressive force originating from the waves causes the piezoelectric to stretch and narrow in order that the position of the charge will change and result in a polarization of charge and voltage. The existence of this polarization then causes a potential difference at the piezo- electric poles. Because the piezoelectric circuits during this system are arranged in parallel, the total voltage generated is the accumulation of the amount of piezoelectrics within the system circuit. Thus, the greater the number of piezoelectrics contained in a circuit, the greater the quantity of voltage generated as shown in Figure 5. The rise within the value of the electrical voltage due to variations in the number of piezoelectrics leads to a rise within the power generated. Furthermore, the increase in the average electric power due to the configuration of the piezoelectric number shows that there is a relationship between the amount of piezoelectric and the power generated. Therefore, the piezoelectric characteristics used in this study shows that the piezoelectric type PZT produced in the form of small sizes has less power ranging from $0.5-8.4 \mathrm{~mW}[28,29]$.

Research on the use of piezoelectrics as an energy harvester from ocean waves shows that with a wave height of 0.05-11.5 meters, the power that can be generated is 60$80 \mathrm{~mW}[30,31]$. Another study utilizing wave pressure on the shoreline and stress according to wave activity obtained an electric power of $12.35 \mathrm{~mW}$ [32]. Furthermore, the research carried out by Cai [33] showed that the electric power generated using the piezoelectric to model from the surface of rivers and sea waves is 0.6 and $0.01 \mathrm{~mW}$.

By considering the time used to measure the amount of voltage and electric current for 5 (five) minutes, and based on the average electric power generated in each configuration, the piezoelectric amount shows that the electric power generated can be used to charge the battery or power bank. For example, if the capacity of the battery or power bank is $1000 \mathrm{mAh}$ with $1.2 \mathrm{~V}$, then to be able to fully charge the battery or power bank from $0-100 \%$, it will take approximately $4.09,2.32$, and 1.40 hours for the average power to be fully charged. When charging the battery, one of the most important factors is electricity, which is largely dependent on the 


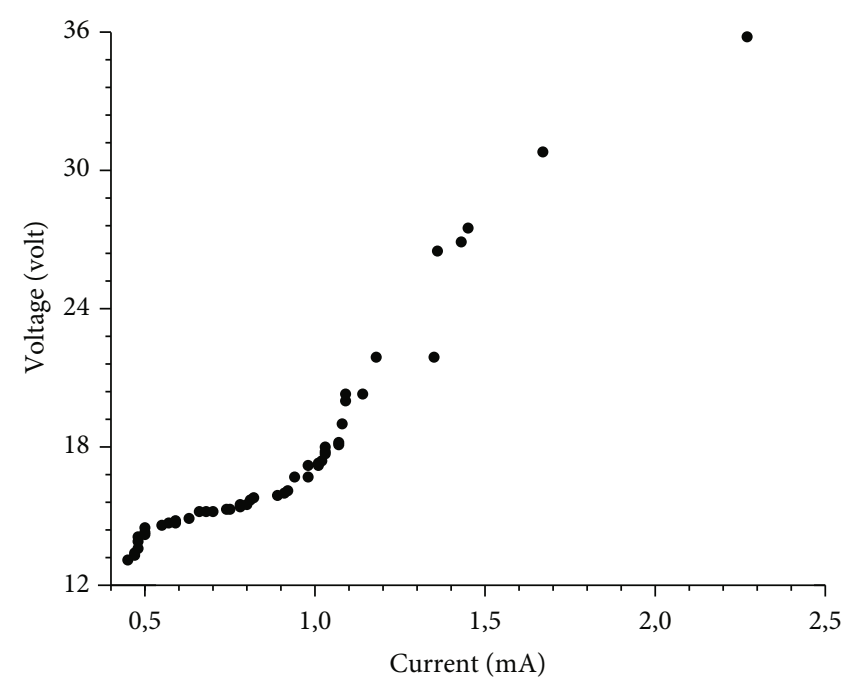

(a)

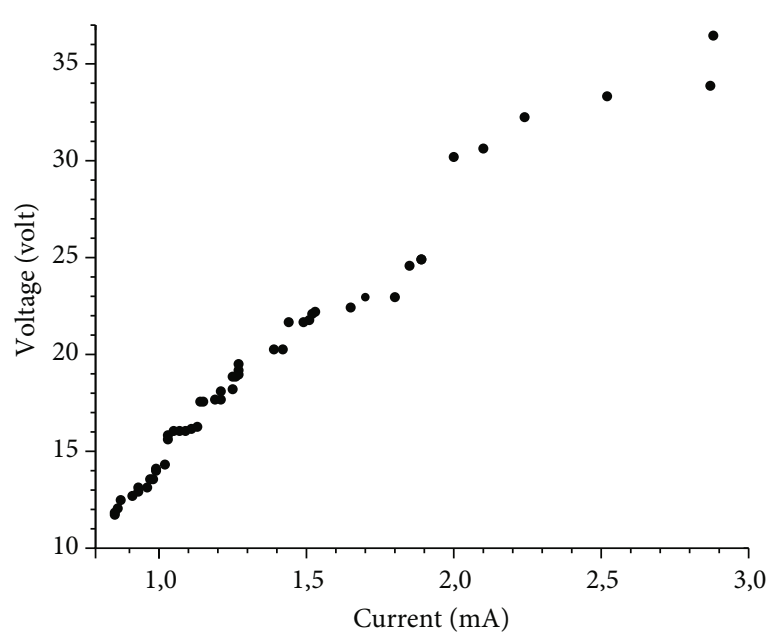

(b)

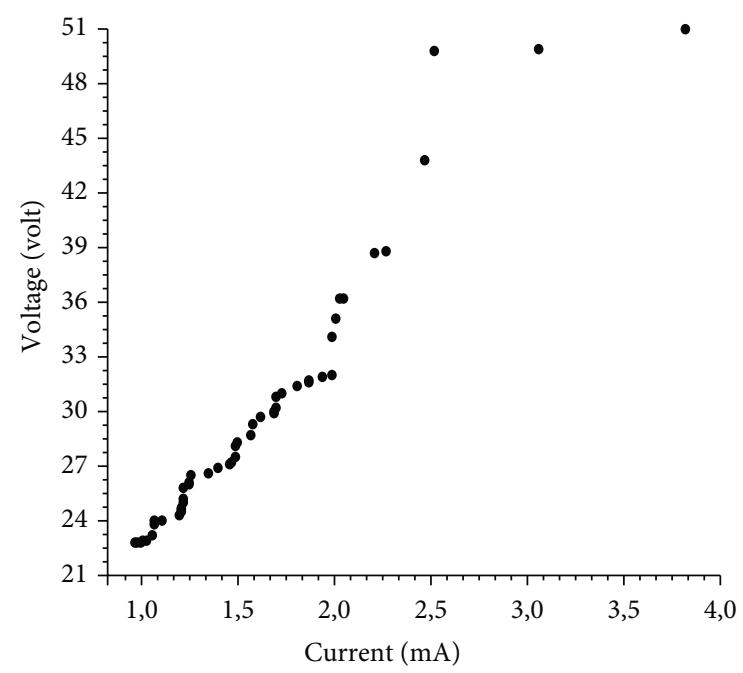

(c)

Figure 6: Curve I-V piezoelectric: (a) 28 pieces; (b) 70 pieces; and (c) 90 pieces.

TABLE 2: Power and electric energy generated by piezoelectric.

\begin{tabular}{|c|c|c|c|c|c|c|}
\hline \multirow{3}{*}{ Piezoelectric quantity (pieces) } & \multicolumn{6}{|c|}{ Calculation results } \\
\hline & \multicolumn{3}{|c|}{ Electrical power $(\mathrm{mW})$} & \multicolumn{3}{|c|}{ Electrical energy $\left(10^{-2} \mathrm{~J}\right)$} \\
\hline & Minimum & Maximum & Average & Minimum & Maximum & Average \\
\hline 28 & 11.66 & 81.27 & 20.39 & 11.88 & 140.98 & 33.98 \\
\hline 70 & 17.00 & 105.12 & 35.92 & 20.35 & 146.55 & 47.41 \\
\hline 98 & 33.97 & 294.32 & 59.92 & 57.18 & 286.11 & 98.03 \\
\hline
\end{tabular}

amount of current supplied [34]. The power supply factor is capable of providing sufficiently large currents, and when it is low, it takes a longer time to charge.

The development of ocean wave energy conversion systems is promising using piezoelectric materials [35]. Therefore, based on the results of the discussion, it can be said that one of the innovative ways to harvest energy is using a piezoelectric device. The energy transformed from ocean waves to electrical control consists of different parallel components, which are needed to be able to transfer and convert the type of energy into electricity. Therefore, components of mechanical equipment, machines with electrical converters, and electronic controllers are needed. This development is still in an early process, and to test its validity, the prototype needs to be trialed based on conditions in several different locations. 


\section{Conclusion}

In conclusion, the configuration of the piezoelectric quantity affects the amount of voltage, current, power, and electrical energy generated through the use of a prototype named Cov-TOTal. The greater the amount of piezoelectric used, the greater the voltage, current, power, and electrical energy generated. Furthermore, when compared with the configuration of the first (28 pieces), second (70 pieces), and third (98 pieces) piezoelectric configuration numbers, there was an increase in the average voltage, current, power, and electrical energy by 18.12 and $69.85 \%, 49.17$ and $73.03 \%, 76.19$ and $193.89 \%$, and 39.51 and $188.47 \%$, respectively.

\section{Data Availability}

The article contains all the relevant data. The corresponding author would provide any additional data upon request.

\section{Disclosure}

The abstract was presented at the " 1 st International Conference on Innovation in Science, Health, and Technology, ICISHT 2020."

\section{Conflicts of Interest}

The authors report no conflicts of interest. The authors alone are responsible for the content and writing of this article.

\section{Acknowledgments}

We would like to thank the Research and Community Service Institute (LPPM) of Gorontalo State University who has funded this research through the basic research scheme of the fiscal year 2020 under contract number: B/116/ UN47. D1/PT.0102/2020.

\section{References}

[1] J. Hong, F. Chen, M. He, S. Wang, W. Chen, and M. Guan, "Study of a Low-Power-Consumption piezoelectric energy harvesting circuit based on synchronized switching technology," Energies, vol. 12, no. 16, p. 3166, 2019.

[2] D. Hill, A. Agarwal, and N. Tong, Assessment of Piezoelectric Materials for Roadway Energy: Cost of Energy and Demonstration Roadmap, California, 2013.

[3] E. Yulia, E. P. Putra, E. Ekawati, and N. Nugraha, "Polisi tidur piezoelektrik sebagai pembangkit listrik dengan memanfaatkan energi mekanik kendaraan bermotor," J. Otomasi Kontrol dan Instrumentasi, vol. 8, no. 1, pp. 105-113, 2016.

[4] F. P. Beer, E. R. Johnston Jr., and J. T. Dewolf, Mechanics of Materials, Fourth, MC Graw Hill, Singapore, 2006.

[5] D. Almanda, E. Dermawan, A. I. Ramadhan, E. Diniardi, and A. N. Fajar, "Analisis desain optimum model piezoelektrik PVDF Untuk sumber pembangkit listrik air hujan berskala mini," Seminar Nasional Sains dan Teknologi 20152015, no. November 2015, pp. 1-5, [Online]. Available: https://jurnal .umj.ac.id/index.php/semnastek/article/viewFile/493/459.
[6] Y. Supriandani and E. Ekawati, "Perancangan dan implementasi karpet piezoelektrik untuk pemanenan energi," Seminar Kontribusi Fisika (SKF), vol. 2015, pp. 145-152, 2015.

[7] E. Lefeuvre, G. Sebald, D. Guyomar, M. Lallart, and C. Richard, "Materials, structures and power interfaces for efficient piezoelectric energy harvesting," Journal of Electroceramics, vol. 22, no. 1-3, pp. 171-179, 2009.

[8] D. Almanda, E. Dermawan, A. I. Ramadhan, E. Diniardi, and S. Hidayat, "Design and test equipment model rain water based energy effect of size of printed material of piezoelectric in Indonesia," Int. J. Eng. Invent., vol. 5, no. 7, pp. 48-55, 2016.

[9] H. Najini and S. A. Muthukumaraswamy, "Investigation on the selection of piezoelectric materials for the design of an energy harvester system to generate energy from traffic," Int. J. Eng. Appl. Sci., vol. 3, no. 2, pp. 43-49, 2016.

[10] W. Hidayatullah, M. Syukri, and S. Syukriyadin, "Perancangan prototype penghasil energi listrik berbahan dasar piezoelectrik," J. Online Tek. Elektro, vol. 1, no. 3, pp. 63-67, 2016.

[11] A. A. Madia, Prototipe alat penghasil listrik dari tekanan mekanik berbasis piezoelektrik, Universitas Hasanudin, 2017.

[12] F. H. Widodo, M. R. Kirom, and A. Qurthobi, Perancangan sistem dan monitoring sumber arus listrik dari lantai piezoelectric untuk pengisian baterai, Bandung, 2017.

[13] A. F. Nuh and W. Hendrowati, "Studi eksperimental energi listrik yang dihasilkan oleh mekanisme ocean wave energy harvester tipe pelampung bola dengan metode cantilever piezoelectric," JTITS, vol. 5, no. 2, pp. 641-646, 2017.

[14] S. O. Saraswati and W. Hendrowati, "Pemodelan dan analisa energi listrik yang dihasilkan mekanisme pembangkit listrik tenaga gelombang air (PLTG-AIR) tipe pelampung silinder dengan cantilever piezoelectric," J. Tek. ITS, vol. 5, no. 2, pp. 337-343, 2017.

[15] D. R. Putra, J. S. Oktoricoento, S. Sahrudin et al., "Energi alternatif melalui getaran beban mekanis," Seminar Nasional Teknoka, vol. 3, pp. 8-17, 2018.

[16] M. Muchtar, "Model kendali generator untuk pembangkit listrik tenaga ombak berbasis gaya gravitasi massa air," Prosiding Seminar Nasional Elektro, pp. 92-95, 2019, Available: https:// perpus.poltekkesjkt2.ac.id/respoy/js/hpdfjs/web/viewer3.php?file=../../../repository//ProsidingSNTE 2018_FIXXX_ 2019.pdf\&loc_name=../../repository//ProsidingSNTE2018_ FIXXX_2019.pdf.

[17] B. Supian, S. Suhendar, and R. Fahrizal, "Studi Pemanfaatan Arus Laut Sebagai Sumber Energi Listrik Alternatif di Wilayah Selat Sunda," Setrum, vol. 2, no. 1, pp. 49-57, 2015.

[18] I. W. A. Wijaya, Pembangkit Listrik Tenaga Gelombang Laut Menggunakan Teknologi Oscilating Water Column di Perairan Bali, Majalah Ilmiah Teknologi Elektro, Bali, 2010.

[19] M. Khoirul, R. Febri, S. Sarwito, and R. Kusuma, "Perancangan Prototype Pembangkit Listrik Tenaga Gelombang Laut Tipe Oscilating Water Column di Pantai Bandealit Jember," Tek. Pomits, vol. 3, no. 1, pp. 138-141, 2014.

[20] L. E. Safitri, M. I. Jumarang, and A. Apriansyah, "Studi Potensi Energi Listrik Tenaga Gelombang Laut Sistem Oscillating Water Column (OWC) di Perairan Pesisir Kalimantan Barat," POSITRON, vol. 6, no. 1, pp. 8-16, 2016.

[21] R. Murray and J. Rastegar, "Novel two-stage piezoelectricbased ocean wave energy harvesters for moored or unmoored buoys," Active and Passive Smart Structures and Integrated Systems 2009, vol. 7288, p. 72880E, 2009. 
[22] A. Afif, S. M. Rahman, A. Tasfiah Azad, J. Zaini, M. A. Islam, and A. K. Azad, "Advanced materials and technologies for hybrid supercapacitors for energy storage - a review," J. Energy Storage, vol. 25, article 100852, 2019.

[23] S. Abrol and C. Deepak, "Experimental investigations of piezoelectric energy harvesting with turbulent flow," Int. J. Mech. Prod. Eng. Res. Dev., vol. 8, no. 1, pp. 703-710, 2018.

[24] T. Li and P. S. Lee, "Piezoelectric energy harvesting with an ultrasonic vibration source," Actuators, vol. 8, no. 1, pp. 8$12,2019$.

[25] C. N. Kumar, "Energy collection via piezoelectricity," Journal of Physics Conference Series, vol. 662, no. 1, p. 012031, 2015.

[26] R. Shreeshayana, L. Raghavendra, and M. V. Gudur, "Piezoelectric energy harvesting using PZT in floor tile design," Int. J. Adv. Res. Electr. Electron. Instrum. Eng., vol. 6, no. 12, pp. 8872-8879, 2017.

[27] X. An, B. Song, W. Tian, and C. Ma, "Design and CFD simulations of a vortex-induced piezoelectric energy converter (VIPEC) for underwater environment," Energies, vol. 11, no. 2, p. 330, 2018.

[28] A. Kumar, R. Kiran, S. Kumar, V. S. Chauhan, R. Kumar, and R. Vaish, "A comparative numerical study on piezoelectric energy harvester for self-powered pacemaker application," Global Challenges, vol. 2, article 1700084, pp. 1-9, 2018.

[29] R. Mishra, S. Jain, C. Durgaprasad, and S. Sahu, "Vibration energy harvesting using drum harvesters," International Journal of Applied Engineering Research, vol. 10, no. 14, pp. 3499535001, 2015.

[30] A. M. Elhalwagy, M. Y. M. Ghoneem, and M. Elhadidi, "Feasibility study for using piezoelectric energy harvesting floor in buildings' interior spaces," Energy Procedia, vol. 115, pp. 114-126, 2017.

[31] M. Safaei, H. A. Sodano, and S. R. Anton, "A review of energy harvesting using piezoelectric materials: state-of-the-art a decade later (2008-2018)," Smart Materials and Structures, vol. 28, no. 11, pp. 113001-113062, 2019.

[32] K.-H. Kim, S.-B. Cho, H.-D. Kim, and K.-T. Shim, "Wave power generation by piezoelectric sensor attached to a coastal structure," J. Sensors, vol. 2018, pp. 1-7, 2018.

[33] W. Cai, Energy Harvesting from Surface River/Ocean Waves, University of Windsor, 2017.

[34] D. Kumar and P. Chaturvedi, "Piezoelectric energy harvesting from vibration induced deformation of floor tiles," National Power Electronics Conference, NPEC 20132013, no. Desember, pp. 1-6, [Online]. Available: http://brihsvn.iitk.ernet.in/ NPEC13/index.php.

[35] M. R. Kiran, O. Farrok, M. Abdullah-Al-Mamun, M. R. Islam, and $\mathrm{W} . \mathrm{Xu}$, "Progress in piezoelectric material based oceanic wave energy conversion technology," IEEE Access, vol. 8, pp. 146428-146449, 2020. 